\title{
Sociale contacten verschuiven als men ouder wordt
}

HANNA VAN SOLINGE, NIDI

Sociale netwerken bestaan uit vrienden, familie, kennissen, buren en collega's. De meeste mensen hebben geregeld contacten met familie, vrienden en buren. Het gaat hierbij om persoonlijke ontmoetingen, telefonische en schriftelijke contacten en om contact via bijvoorbeeld e-mail, sms, chat of door berichtjes te sturen.

Acht op de tien mensen heeft minstens een keer per week contact met één of meer familie- of gezinsleden die niet in huis wonen. Er zijn op dit punt nauwelijks verschillen tussen de leeftijdsgroepen. Die zijn er wel bij de andere categorieën. De jongste leeftijdsgroe- pen hebben frequenter contact met vrienden, terwijl ouderen frequenter contact hebben met buren. Het oudhollands spreekwoord 'Beter een goede buur, dan een verre vriend' lijkt hier van toepassing.

Slechts weinig mensen hebben geen of nauwelijks sociale contacten. Zes tot zeven procent heeft minder dan een keer per maand contact met familie of vrienden. Een op de vijf heeft nauwelijks contact met buren. Wie geen of weinig sociale contacten heeft, hoeft zich niet perse eenzaam te voelen. Sociaal isolement ligt hier echter wel op de loer.

\begin{tabular}{lllllll}
\hline & \multicolumn{2}{c}{ minstens een keer per week } & \multicolumn{3}{c}{ minder dan een keer per maand } \\
\hline & familie & vrienden & buren & familie & vrienden & buren \\
\hline 15-25 jaar & 79 & 95 & 48 & 6 & 2 & 32 \\
\hline 25-35 jaar & 90 & 88 & 48 & 2 & 3 & 26 \\
\hline $35-45$ jaar & 86 & 79 & 62 & 4 & 9 & 18 \\
\hline $45-55$ jaar & 79 & 71 & 61 & 6 & 10 & 17 \\
\hline $55-65$ jaar & 79 & 66 & 60 & 8 & 8 & 13 \\
\hline $65-75$ jaar & 81 & 73 & 72 & 6 & 13 & 14 \\
\hline 75 jaar en ouder & 80 & 65 & 72 & 7 & & 20 \\
\hline Alle leeftijden & 82 & 77 & 60 & 6 & 7 & 2 \\
\hline
\end{tabular}

Bron: CBS 2017 